\title{
Preterm and infection-driven preterm labor: the role of peroxisome proliferator-activated receptors and retinoid $X$ receptor
}

\author{
Sarah J Holdsworth-Carson ${ }^{1,2}$, Michael Permezel ${ }^{1,2}$, Greg E Rice ${ }^{3}$ and Martha Lappas ${ }^{1,2}$ \\ ${ }^{1}$ Department of Obstetrics and Gynaecology, Mercy Hospital for Women, University of Melbourne, Level 4/163 \\ Studley Road, Heidelberg, Victoria 3084, Australia, ${ }^{2}$ Mercy Perinatal Research Centre, Mercy Hospital for Women, \\ Heidelberg, Victoria 3084, Australia and ${ }^{3}$ Translational Proteomics, Baker IDI, Melbourne, Victoria 3004, Australia \\ Correspondence should be addressed to M Lappas at Department of Obstetrics and Gynaecology, Mercy Hospital for Women, \\ University of Melbourne; Email: mlappas@unimelb.edu.au
}

\begin{abstract}
Approximately $8 \%$ of births are complicated by preterm delivery. To improve neonatal outcomes, a greater understanding of the mechanisms surrounding preterm parturition is required. Peroxisome proliferator-activated receptors (PPARs) have been implicated in the regulation of labor at term where they exhibit anti-inflammatory properties. Thus, we hypothesize that dysregulation of PPAR expression and activity may be associated with preterm labor and infection-associated preterm labor. The aim of this study was to compare the expression and activity of PPARs and the expression of retinoid X-receptor $\alpha$ (RXRA) in gestational tissues from term and preterm deliveries, and from infection-associated preterm deliveries. Quantitative RT-PCR, western blotting and activity ELISA were used to study expression and DNA binding profiles. Compared with term, preterm parturition was associated with an increased expression of PPAR $\delta$ (PPARD; mRNA and protein), PPAR $\gamma$ (PPARG; protein) and RXRA (protein) in the placenta and PPARD (mRNA and protein) and RXRA (mRNA) in the choriodecidua. There was, however, no change in preterm PPAR DNA binding activity compared with term. Preterm chorioamnionitis (CAM) demonstrated protein degradation in the choriodecidua and was associated with a decline in the mRNA expression of PPAR $\alpha(P P A R A)$ and RXRA compared with uninfected preterm cases. PPAR DNA binding activity increased in the placenta (PPARD and PPARG) and decreased in the amnion (PPARA and PPARG) in association with preterm CAM. In conclusion, idiopathic preterm deliveries were associated with an increase in PPAR:RXR expression and preterm CAM was associated with a decrease in PPAR:RXR expression and tissue-specific alterations in transcriptional activity. The reasons for such dysregulation remain to be determined; however, the data are consistent with the hypothesis that PPARs may play a role in preterm labor and infection-complicated preterm deliveries.

Reproduction (2009) 137 1007-1015
\end{abstract}

\section{Introduction}

Approximately $8 \%$ of births occur before 37 weeks complete gestation, with the majority of preterm births occurring between 32 and 36 weeks (Laws et al. 2007, Saigal \& Doyle 2008). Spontaneous premature delivery is the leading cause of neonatal mortality and is responsible for neonatal morbidity including respiratory distress, temperature instabilities, and feeding complications (Laws et al. 2007, Saigal \& Doyle 2008). Neurodevelopmental, respiratory, and gastrointestinal problems are common into early childhood (Goldenberg et al. 2008, Saigal \& Doyle 2008). The causes of preterm labor remain unresolved; possibly representing the activation of normal labor mechanisms, albeit too early, or resulting from adverse pathological complications (Lamont 2001, Goldenberg et al. 2002, Romero et al. 2006). To improve preterm morbidity and mortality, a greater understanding of the processes associated with preterm labor are required.

Although a large degree of preterm births are idiopathic, intra-amniotic infection has been implicated in reduced gestational duration, especially in earlier deliveries < 30 weeks (Goldenberg et al. 2002, Romero et al. 2006, Gargano et al. 2008). Chorioamnionitis (CAM), inflammation of the amniochorion, is caused by ascending bacterial infection from the lower genital tract (Fahey 2008). Organisms colonize the chorioamnionic surface and sequential inflammatory responses are activated in the chorionic plate (acute subchorionitis; Stage 1); the membranous chorion (acute chorionitis; also Stage 1); the connective tissue of the chorion and amnion (acute CAM; Stage 2); and lastly causing amnion epithelial cell necrosis (necrotizing CAM; Stage 3; Redline 2006). 
Peroxisome proliferator-activated receptors (PPARs) have been implicated in several aspects of early pregnancy development including implantation, placentation, and trophoblast differentiation (Barak et al. 1999, Lim \& Dey 2000, Tarrade et al. 2001). We and others have presented data implicating PPARs in the inflammatory events that contribute to normal labor at term (Lim \& Dey 2000, Lappas et al. 2002b, 2004, Berry et al. 2003, Dunn-Albanese et al. 2004, Ackerman et al. 2005, Lindstrom \& Bennett 2005, Froment et al. 2006, Schaiff et al. 2006, Fournier et al. 2007, Holdsworth-Carson et al. 2009). PPARs exhibit anti-inflammatory properties (Jiang et al. 1998, Ricote et al. 1998, Delerive et al. 2001, Daynes \& Jones 2002, Lappas et al. 2002 b, Kielian et al. 2008, Perez et al. 2008) and are hypothesized to promote pregnancy quiescence and initiate labor (Dunn-Albanese et al. 2004, Froment et al. 2006, Schaiff et al. 2006, Wieser et al. 2008). There are three isoforms of PPAR nuclear receptors ( $\alpha$ (PPARA), $\delta$ (PPARD), and $\gamma$ (PPARG)) and they act as liganddependent transcription factors (Issemann \& Green 1990, Dreyer et al. 1992). Activation by binding of ligand results in nuclear translocation where PPAR binds to specific sequences within the promoter regions of target genes (peroxisome proliferator responsive elements (PPRE)). Once bound to the PPRE site, PPAR will either activate or inhibit gene expression. Co-operative heterodimerization of PPAR to retinoid $X$ receptor (RXR) is obligatory for PPAR-dependent gene transcription (Mangelsdorf \& Evans 1995).

PPAR isoforms and RXRA have been identified in human gestational tissues (Berry et al. 2003, DunnAlbanese et al. 2004, Borel et al. 2008, HoldsworthCarson et al. 2009). Research has inferred a role for PPAR in preterm labor (Schaiff et al. 2006, Borel et al. 2008, Wieser et al. 2008) and carriers of a PPARG genetic polymorphism have been associated with being born prematurely (Meirhaeghe et al. 2007). PPAR-associated inflammatory mediator suppression suggests that a breakdown in PPAR expression or activity may be apparent during periods of preterm intra-amniotic infection, as seen in non-gestational tissue infections (Kielian et al. 2008, Perez et al. 2008). While some groups have investigated PPAR expression in first (Tarrade et al. 2001, Capparuccia et al. 2002, Rodie et al. 2005) and second trimester placenta (Waite et al. 2000, Rodie et al. 2005) and serum samples throughout the course of pregnancy (Wieser et al. 2008), data are lacking regarding the expression and activity of PPAR isoforms in association with preterm delivery, with and without infection. The aim of this study was to compare the expression and DNA binding activity patterns of PPAR isoforms and the expression of RXRA in human gestational tissues from term and preterm vaginal deliveries, and to determine the effect of infectionassociated preterm delivery on PPAR isoforms and RXRA expression. We propose that downregulation in PPAR expression and/or DNA binding activity is apparent during preterm labor, more so in infection-complicated preterm deliveries, thereby promoting inflammatory mediated pro-labor mechanisms.

\section{Results}

\section{Clinical characteristics of the patients}

Table 1 presents the clinical characteristics for the patients included in this study. The term and preterm women (without infection) all went into spontaneous labor and delivered vaginally. The term women all had spontaneous rupture of the fetal membranes with labor, while most of the preterm women $(83 \%)$ had pre-labor rupture of membranes (PROM; McParland \& Bell 2004). The duration of fetal membrane rupture was significantly less in the term group compared with the preterm group. It should be noted that one patient in the preterm group had PROM 14 days prior to spontaneous labor onset and delivery. Gestational age and fetal weight were significantly lower in the preterm group. Although maternal body mass index at $\sim 12$ weeks gestation was significantly higher for women who delivered at term, the mean value was still within the healthy range.

Table 1 Clinical details of tissues collected from term, preterm and preterm chorioamnionitis deliveries (mean \pm s.E.M).

\begin{tabular}{|c|c|c|c|}
\hline Clinical feature & $\begin{array}{l}\text { Term } \\
(n=6)\end{array}$ & $\begin{array}{c}\text { Preterm } \\
(n=6)\end{array}$ & $\begin{array}{l}\text { Chorioamnionitis } \\
\quad(n=8)\end{array}$ \\
\hline $\begin{array}{l}\text { Weeks gestation } \\
\text { Labor status }\end{array}$ & $40.2 \pm 0.4^{*}$ & $34.7 \pm 0.4$ & $31.2 \pm 1.0^{+}$ \\
\hline Spontaneous & $100 \%(6 / 6)$ & $100 \%(6 / 6)$ & $87.5 \%(7 / 8)$ \\
\hline Induced & - & - & $12.5 \%(1 / 8)$ \\
\hline \multicolumn{4}{|l|}{ Delivery mode } \\
\hline Vaginal & $100 \%(6 / 6)$ & $100 \%(6 / 6)$ & $37.5 \%(3 / 8)$ \\
\hline Caesarean section & - & - & $62.5 \%(5 / 8)$ \\
\hline \multicolumn{4}{|l|}{ Membrane rupture } \\
\hline SROM & $100 \%(6 / 6)$ & $17 \%(1 / 6)$ & - \\
\hline PROM & - & $83 \%(5 / 6)$ & $50 \%(4 / 8)$ \\
\hline ARM & - & - & $50 \%(4 / 8)$ \\
\hline Rupture duration & $\begin{array}{l}5 \text { h } 25 \text { min } \\
\quad \pm 1 \text { h } 2 \text { min* }\end{array}$ & $\begin{array}{l}14 \mathrm{~h} \\
8 \min \pm 4 \mathrm{~h} \\
2 \min \end{array}$ & $>24 \mathrm{~h}(\mathrm{PROM})$ \\
\hline \multicolumn{4}{|l|}{ Histopathology } \\
\hline $\begin{array}{l}\text { Chorioamnionitis } \\
\text { Stage } 1\end{array}$ & - & - & $50 \%(4 / 8)$ \\
\hline $\begin{array}{l}\text { Chorioamnionitis } \\
\text { Stage } 2\end{array}$ & - & - & $50 \%(4 / 8)$ \\
\hline Fetal weight (g) & $3645.8 \pm 92.7^{*}$ & $\begin{array}{l}2366.3 \\
\quad \pm 129.2\end{array}$ & $1753.9 \pm 166.9^{+}$ \\
\hline $\begin{array}{l}\text { Fetal sex } \\
\quad(\% \text { female })\end{array}$ & $33 \%(2 / 6)$ & $33 \%(2 / 6)$ & $25 \%(2 / 8)$ \\
\hline Apgar 5 min & $9.0 \pm 0.0$ & $8.8 \pm 0.5$ & $8.5 \pm 0.6$ \\
\hline $\begin{array}{l}\text { Maternal age } \\
\text { (years) }\end{array}$ & $31.0 \pm 1.6$ & $32.2 \pm 1.3$ & $28.5 \pm 1.6$ \\
\hline $\begin{array}{l}\text { Twelve week BMI } \\
\left(\mathrm{kg} / \mathrm{m}^{2}\right)\end{array}$ & $24.2 \pm 0.7^{*}$ & $20.6 \pm 1.1$ & $21.0 \pm 1.0$ \\
\hline
\end{tabular}

SROM, spontaneous rupture of membranes with labor; PROM, prelabor rupture of membranes) and ARM, artificial rupture of membranes, either during labor or at Caesarean section. *Denotes significant difference between term and preterm $(P<0.05)$. ${ }^{\dagger}$ Denotes significant difference between preterm and chorioamnionitis $(P<0.05)$. 
Compared to preterm patients without infection, women with histopathologically diagnosed CAM displayed variability with respect to labor type (spontaneous versus induced labor) and mode of delivery (vaginal versus Caesarean section). This reflects the unpredictability of CAM infection and the degree of medical intervention involved in treatment, where prompt delivery of the infant is often the safest option for mother and baby (Fahey 2008). In comparison with the noninfected preterm women, CAM women delivered infants with significantly lower gestational age and fetal weight.

\section{The effect of term and idiopathic preterm gestations on PPAR and RXRA mRNA expression, protein expression, and DNA binding activity in spontaneous vaginal deliveries}

\section{$m R N A$ and protein expression}

Quantitative RT-PCR (qRT-PCR) and western blotting was used to determine PPARA, -D and -G, and RXRA mRNA and nuclear protein expression between term and preterm deliveries, in placenta, amnion, and choriodecidua (Fig. 1). There was no difference in PPARA mRNA or nuclear protein expression between the term and preterm groups for placenta (Fig. 1a, b and j). PPARG mRNA expression also remained unchanged between the two gestational groups for placenta. By contrast, mRNA expression for PPARD and nuclear protein expression of PPARD, PPARG, and RXRA were all significantly higher at preterm when compared with term placental samples $(P<0.05$; Fig. $1 \mathrm{a}, \mathrm{b}$ and $\mathrm{j})$.

For amnion, mRNA and protein expression was unchanged between the term and preterm deliveries for all PPARs and RXRA (Fig. 1d, e and k). As previously published, PPARA protein was undetectable in amnion nuclear fractions (Holdsworth-Carson et al. 2009). For choriodecidua, PPARD nuclear protein and PPARD and $R X R A$ mRNA expression was significantly higher in the preterm group compared with the term group $(P<0.05$; Fig. $1 \mathrm{~g}, \mathrm{~h}$ and $\mathrm{I})$. There was no difference in PPARA and PPARG mRNA expression, and PPARA, PPARG and RXRA nuclear protein expression between preterm and term groups for choriodecidua.
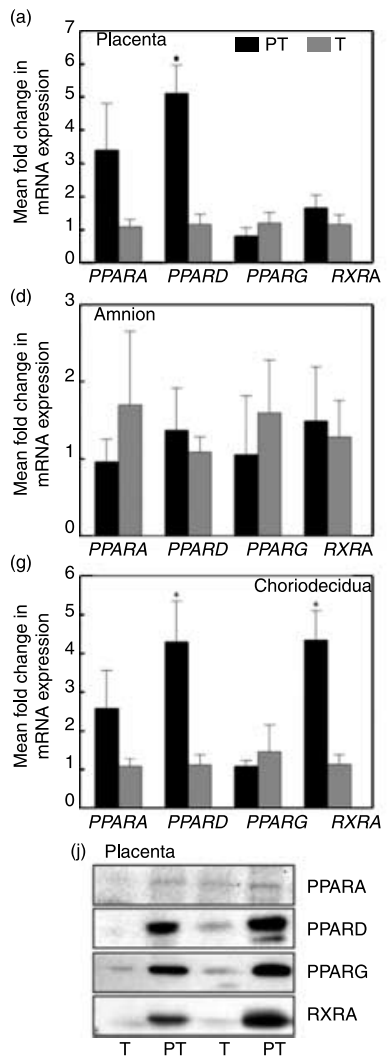
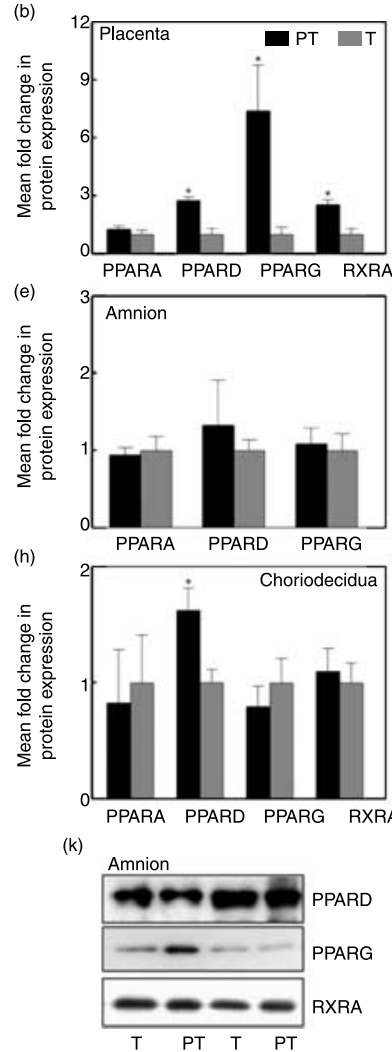
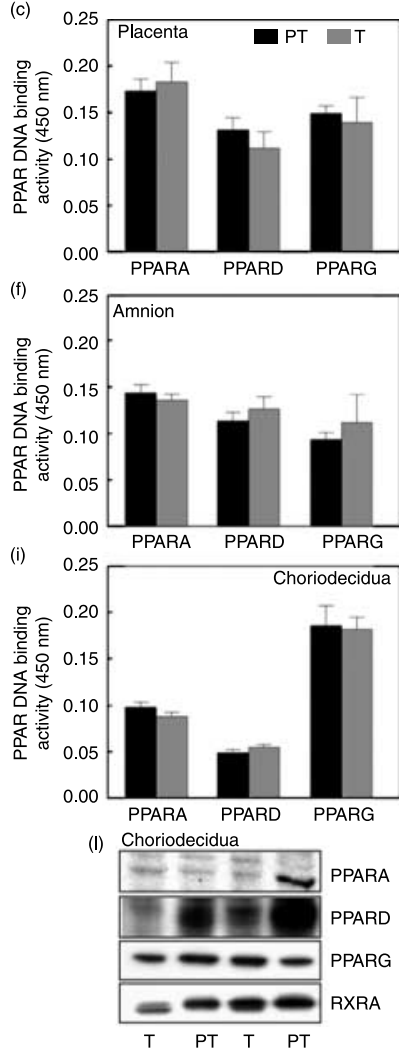

Figure 1 PPAR isoform and RXRA mRNA expression, protein expression and DNA binding activity in idiopathic preterm and term spontaneous vaginal deliveries. GRT-PCR, western blotting, and activity ELISA were performed on preterm (PT) and term (T) $(\mathrm{a}-\mathrm{C})$ placenta, $(\mathrm{d}-\mathrm{f})$ amnion, and $(\mathrm{g}-\mathrm{i})$ choriodecidua. PT mRNA, nuclear protein and DNA binding activity were compared with T by two-sample comparison (Students $t$-test). Expression is displayed as the mean fold change ratio \pm S.E.M. and DNA binding activity is displayed as the mean optical density (at $450 \mathrm{~nm}$ ) minus the blank \pm S.E.M. with $P$ values $<0.05$ denoted with *. Representative western blot images for PPARA, $-\mathrm{D},-\mathrm{G}$, and RXRA are displayed in (j) placenta, (k) amnion and (I) choriodecidua. Note that PPARA nuclear protein could not be detected. 


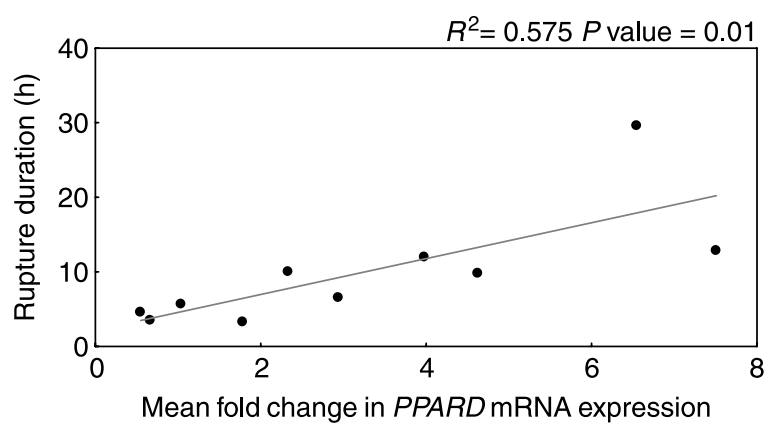

Figure 2 Correlation between PPARD mRNA expression and fetal membrane rupture duration in term and idiopathic preterm placenta. Correlation analyses (linear) were performed on fetal membrane rupture duration and qRT-PCR data from five term women and five preterm women $\left(R^{2}=0.575\right.$ and $P$ value $\left.=0.01\right)$.

\section{PPAR DNA binding activity}

PPAR DNA binding activity was measured from nuclear protein extracts of placenta, amnion, and choriodecidua (Fig. 1c, f, and i). No significant changes in DNA binding activity for any PPAR isoform were detected in placenta, amnion or choriodecidua when comparing preterm gestations to term gestations.

\section{Effect of duration of fetal membrane rupture on PPAR isoforms and RXRA}

Correlation analysis was performed between the duration of fetal membrane rupture (Table 1) and the mRNA and protein expression of PPARs and RXRA and the DNA binding activities of PPAR isoforms (Fig. 1). Analysis revealed that PPARD mRNA expression in the placenta is positively associated with rupture duration $(P<0.01$; Fig. 2$)$. None of the other variables tested shared a significant relationship (data not shown).

\section{The effect of CAM on PPAR and RXRA mRNA expression, protein expression, and DNA binding activity in preterm deliveries}

qRT-PCR and western blotting were used to demonstrate differences in expression of PPARA, -D, and -G and RXRA between preterm deliveries, with and without histological CAM, in placenta, amnion, and choriodecidua (Fig. 3). Patients with CAM were stratified according to degree of infection; Stage 1 or Stage 2 CAM (Redline et al. 2003, Redline 2006), and compared individually to preterm patients without infection. Stage 1 and 2 CAM were also combined (CAM $(1+2)$ ) and compared separately to preterm patients without infection.

\section{mRNA expression}

There was no significant effect of CAM on placental and amnion mRNA expression of all PPAR isoforms and RXRA (Fig. 3a and d). Furthermore, choriodecidual $P P A R D$ and $-G$ mRNA expression was also unchanged between the preterm groups with and without infection (Fig. 3g). By contrast, PPARA mRNA from the CAM $(1+2)$ group was significantly lower than the noinfection preterm group for choriodecidua $(P<0.05$; Fig. $3 g$ ). In addition, RXRA mRNA in the choriodecidua was significantly reduced in the Stage 1 CAM group compared with the non-infected preterm group $(P<0.05$; Fig. 3g).

\section{Protein expression}

Analysis of PPAR protein expression was based on whole cell protein extracts as nuclear protein extracts displayed severe CAM-associated protein degradation (data not shown). Stage 2 CAM was associated with protein degradation in all of the choriodecidua samples (Fig. $3 \mathrm{~h}$ and $\mathrm{j}$ ). It is likely that protein degradation was a result of loss of tissue integrity. Previously published examples of this include: chorion layer loss in preterm CAM membranes (Premyslova et al. 2003); extensive chorion, amniotic epithelium and decidual stromal cell integrity loss with Stage 3 preterm CAM (Van Meir et al. 1996, 1997); and destruction of chorion trophoblasts with CAM in rhesus monkey fetal membranes (Giannoulias et al. 2005). Stage 1 CAM choriodecidua samples were also associated with some loss of protein (see Fig. $3 \mathrm{j}$ ). Both tubulin and $\beta$-actin clearly demonstrate the protein degradation in lanes 2, 3, 6, and 9. Thus, the effect of CAM Stage 2 on choriodecidual PPAR isoform and RXRA protein expression could not be performed. When compared with Stage 1 CAM, there was no significant difference in PPAR and RXRA protein expression in preterm choriodecidua samples (Fig. 3h).

There were no infection-associated changes in PPAR isoform and RXRA protein expression in the placenta (Fig. 3b) and amnion (Fig. 3e). It should be noted that in amnion, one patient showed protein degradation associated with Stage 2 CAM, this patient was therefore excluded from the amnion analysis.

\section{PPAR DNA binding activity}

PPAR DNA binding activity was measured in idiopathic preterm and preterm CAM-infected pregnancies using nuclear extracts of placenta, amnion, and choriodecidua, see Fig. 3c, f, and i. Patients with CAM were stratified as above and compared individually with preterm patients without infection. Stage 1 and 2 CAM were also combined (CAM $(1+2))$ and compared separately with idiopathic preterm patients.

PPAR DNA binding activity did not differ between Stage 1 CAM and uninfected preterm deliveries in choriodecidua (Fig. 3i). Since Stage 2 CAM was associated with protein loss, analysis of Stage 2 CAM in choriodecidua could not be performed. PPARA DNA binding activity was unchanged in placental tissue between preterm and infected groups (Fig. 3c). Both PPARD and PPARG isoforms, however, demonstrated an 
(a)

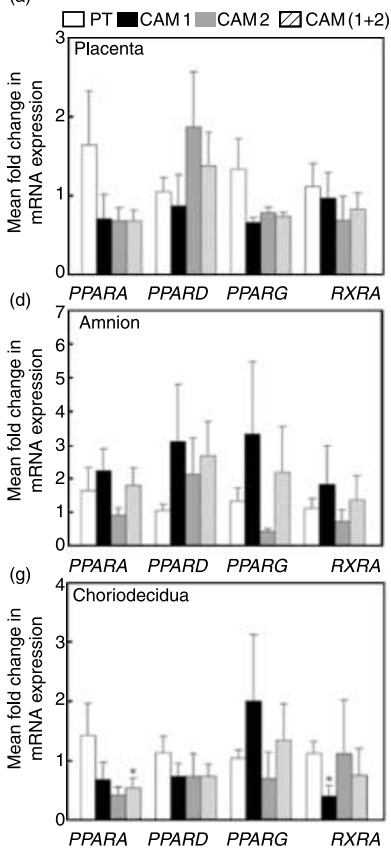

(b)

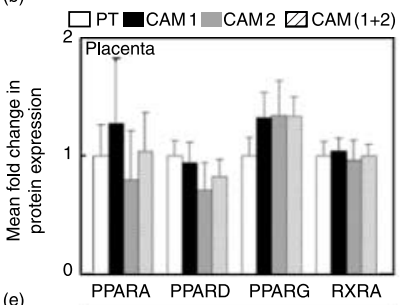

(e)
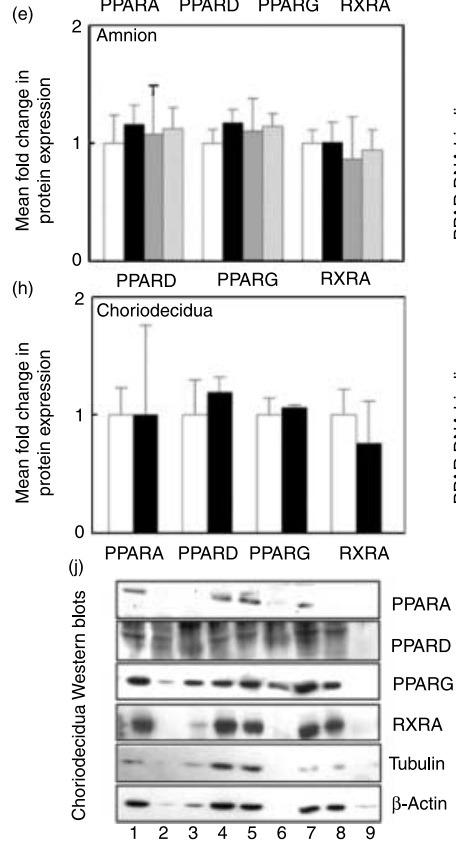

(c)
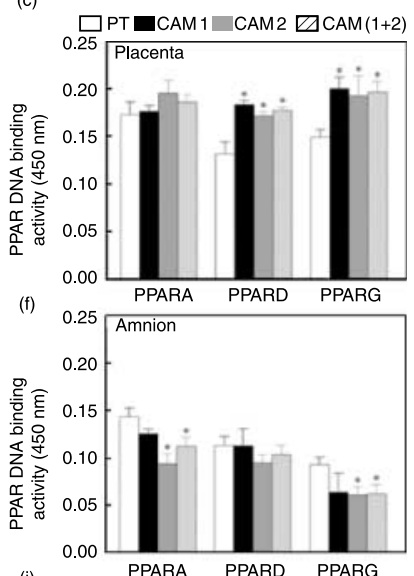

(i)

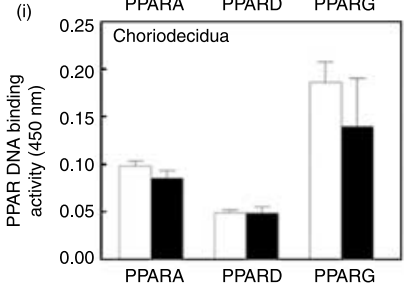

Figure 3 PPAR isoform and RXRA mRNA expression, protein expression, and DNA binding activity in idiopathic preterm and chorioamnionitis preterm deliveries. qRT-PCR, western blotting, and activity ELISA were performed on PT (a-C) placenta, (d- $\mathrm{f}$ ) amnion, and ( $\mathrm{g}-\mathrm{i}$ ) choriodecidua, with and without CAM infection. CAM infection is categorized according to stage of infection; Stage 1 CAM, Stage 2 CAM, and combined as CAM (1 + 2 ). Expression is displayed as the mean fold change ratio \pm s.E.M. and DNA binding activity is displayed as the mean optical density (at 450 nm) minus the blank \pm S.E.M. Preterm non-infected expression was compared with CAM expression by two-sample comparison (Students $t$-test). Significant difference $(P$ value $<0.05)$ as compared with PT no infection is denoted with a *. Representative choriodecidual western blot images for PPARA, PPARD, PPARG, RXRA, tubulin, and $\beta$-actin are displayed in (j). Lanes 1, 4, and 7 are PT non-infected. Lanes 2, 5, and 8 are PT CAM (Stage 1). Lanes 3, 6, and 9 are PT CAM (Stage 2).

increase in DNA binding activity in association with CAM. Stage 1 and Stage 2 CAM all displayed significantly higher activity in placenta compared with preterm patients without infection $(P<0.05)$. In amnion, PPARA and PPARG DNA binding activity was significantly lower in association with Stage 2 CAM and CAM $(1+2)$ compared with idiopathic preterm patients (Fig. 3f). PPARD DNA binding activity did not differ when comparing infected and non-infected patients in the amnion.

\section{Discussion}

The present study reports unique observations comparing mid-third trimester to late-third trimester gestations and the expression and activity of PPAR isoforms and expression of RXRA. Specifically, we have shown that compared with term, preterm parturition at $\sim 34$ weeks gestation is associated with increased expression of PPARD, PPARG, and RXRA in the placenta and PPARD and RXRA in the choriodecidua. Preterm CAM, while demonstrating protein degradation in the choriodecidua, was found to be associated with lower expression of choriodecidual PPARA and RXRA mRNA, lower PPARA and PPARG DNA binding activity in the amnion and increased PPARD and PPARG activity in the placenta when compared with uninfected preterm cases.

In this study, PPARA (mRNA, nuclear protein and activity) and PPARG mRNA expression and activity in placenta, amnion, and choriodecidua were unaltered between preterm and term gestations. PPARG nuclear protein expression in amnion and choriodecidua was also unchanged, indicating that PPARA and PPARG (in the fetal membranes) are not affected by preterm parturition. In support of this, PPARA protein has previously been described as being undetectable in first and second trimester placenta (Waite et al. 2000), 
while no changes in placental PPARG protein expression between first and third trimester placentas have been reported (Capparuccia et al. 2002).

We observed an increase in the expression of PPARG nuclear protein in the preterm placenta which is in contrast to our observed PPARG mRNA expression and the findings of Capparuccia et al. (2002). This indicates tissue-specific expression patterns and a posttranscriptional modification in PPARG processing. The discrepancy between protein findings are probably due to different protein preparation techniques, for example we used nuclear fractions to show nuclear receptor localization compared with the whole cell lysates used by Capparuccia et al. (2002). RXRA expression was also observed to be increased in the placenta (mRNA and protein) and choriodecidua (mRNA) at preterm compared with term, demonstrating the co-operative partnership between PPARs and RXRA. By contrast, Wang et al. (2002) reported increased placental $R X R A$ mRNA expression with increasing gestational age in rats.

PPARD mRNA and protein expression in the placenta and choriodecidua are increased during the mid-third trimester and then decline significantly at term. Like PPARA and PPARG, however, we saw no change in PPARD DNA binding activity. Therefore, all PPAR isoform DNA binding transcriptional activities are unaffected by gestational age (comparing mid- to latethird trimester). Suggesting that PPARs may be influencing gene expression of non-PPRE targets in a non-DNA binding capacity, including by post-translational modifications, transrepression or sequestering of co-activator proteins (Bensinger \& Tontonoz 2008). Increased expression of PPARD mRNA was found to be significantly related to longer fetal membrane rupture duration, a characteristic significantly associated to prematurity. By contrast, others have reported that PPARD mRNA and protein in the placenta either increase with increasing gestational age or remain unchanged (Wang et al. 2002, Rodie et al. 2005). The study by Rodie et al. (2005) compared first trimester to term placenta, whereas we examined mid- to late-third trimester gestational tissues, thus identifying a novel change in PPARD expression.

We suggest that the higher expression of PPARD, PPARG and RXRA seen in our preterm groups may represent a PROM-related mechanism opposed to spontaneous fetal membrane rupture with labor. The women included in our investigation all went into spontaneous labor (collected post-labor), therefore we can conclude that the changes observed are not laborassociated. Clinically, the main differences between the preterm and term women were PROM and consequently longer fetal membrane rupture duration in the preterm group. PROM is a complication of pregnancy that can occur at any gestation; however, it is associated with $20-50 \%$ of preterm births (French \& McGregor 1996). The causes of PROM are numerous, and in part are caused by apoptosis and inflammatory cytokines (Fortunato \& Menon 2001, Menon \& Fortunato 2004, Reti et al. 2007). Increased expression or activation of PPARs have been associated with apoptosis (Keelan et al. 2001, Yang \& Frucht 2001, Wieser et al. 2008) and pro-inflammatory cytokines (Ackerman et al. 2005).

Preterm labor often results from CAM (Fahey 2008). Bacterial infections evoke an acute inflammatory response, which in turn is modulated by PPAR (Delerive et al. 2001, Daynes \& Jones 2002). CAM infection is confined to the fetal membranes, either chorion alone (Stage 1) or both the amnion and chorion (Stage 2), therefore the lack of PPAR:RXR expression response observed in the placenta is not surprising. In contrast to our original hypothesis, PPARD and PPARG DNA binding activity increased in association with CAM in the placenta. It is possible that the increased PPAR transcriptional activity may be a compensatory mechanism, whereby inflammatory products released from the fetal membranes may be acting in a paracrine fashion to assist in controlling the inflammatory insult. In support of this hypothesis, we have previously shown that PPAR and RXRA expression is increased at term during active labor, at the height of parturition-related inflammatory activity, compared with before labor onset and post-labor (Holdsworth-Carson et al. 2009). Furthermore, in a non-gestational tissue model, PPAR expression was enhanced in response to infection with Chlamydia pneumoniae (Kim et al. 2008). Therefore, PPAR DNA binding activity does not necessarily correlate to receptor expression, indicating that regulation of PPAR activity is controlled independent of transcription factor bioavailability.

Stage 2 preterm CAM was associated with a decrease in PPARA and PPARG DNA binding activity in amnion. Furthermore, choriodecidual CAM $(1+2)$ samples were associated with lower expression of PPARA and RXRA mRNA. Similarly, investigations in mouse adipose and kidney tissues with bacterial endotoxin exposure have demonstrated reduced PPARA, PPARG, and RXRA mRNA expression (Hill et al. 1997, Feingold et al. 2008). Although DNA binding activity remained unaltered, the CAM-induced decrease in mRNA expression suggests that the anti-inflammatory properties of the PPAR and RXR may also be diminished in the choriodecidua. We propose that the decrease in PPAR in fetal membranes with CAM may activate the pro-inflammatory mechanisms associated with acute inflammation, thus lending supports our hypothesis that dysregulation of PPAR expression could be associated with infection-complicated preterm deliveries.

In summary, the data obtained are consistent with the hypothesis that the expression of PPARD, PPARG, and RXRA in placenta and choriodecidua are modified in association with preterm spontaneous vaginal delivery. This heightened expression may be a consequence of PROM. CAM-associated preterm 
cases, although associated with protein degradation in choriodecidua, demonstrated decreased PPARA and RXRA mRNA. PPAR DNA binding activity was found to be increased in the placenta and decreased in the amnion in association with preterm CAM. These data demonstrate potential divergent roles for PPARs and RXRA in preterm parturition and associated complications, with tissue-specific and isoform-specific mechanisms involved. Further studies are, however, required to uncover the exact role of PPAR in human preterm labor, with and without histological CAM.

\section{Materials and Methods}

\section{Reagents}

Mouse monoclonal $\beta$-actin antibody (A5316) and TRI reagent were supplied by Sigma. Pancreatic deoxyribonuclease (DNase I) was supplied by GE Healthcare (Rydalmere, NSW, Australia). The following antibodies and reagents were purchased from Santa Cruz Biotechnology Inc. (Santa Cruz, CA, USA) ponceau-S, western blotting luminol reagent, rabbit polyclonal PPARA sc-9000, rabbit polyclonal PPARD (PPAR- $\beta(\delta))$ SC-7197, rabbit polyclonal PPARG SC-7196, rabbit polyclonal RXRA sc-553, mouse monoclonal $\beta$-tubulin sc-5274, goat anti-rabbit IgG-HRP sc-2004 and goat anti-mouse IgG-HRP sc-2005. iScript cDNA synthesis kit was purchased from BioRad Laboratories. Predesigned bioinformatically validated QuantiTect primer assays for 18s QT00199367, $\beta$-actin QT00095431, PPARA QT00017451, PPARD QT00078064, PPARG QT00029841, and RXRA QT00005726 were purchased from Qiagen. SensiMixPlus SYBR and fluorescein was purchased from Quantace (Alexandria, NSW, Australia). Coomassie Plus Protein Assay and BCA Protein Assay reagents were from Pierce (Rockford, IL, USA). PPARA, -D, -G complete transcription factor assay kit was purchased from Cayman Chemical (Ann Arbor, MI, USA).

\section{Tissue collection and preparation}

Human placentae and attached fetal membranes $(n=14)$ were obtained (with the Research Ethics Committee of Mercy Health and Aged Care approval) from consenting women who delivered singleton infants at preterm ( $<37$ weeks gestation) with and without CAM. Term placentae and fetal membranes $(n=6)$ were collected from women with uncomplicated pregnancies, who went into natural labor, with spontaneous rupture of the fetal membranes and delivered vaginally. Term patients exhibited no clinical signs of infection. Refer to Table 1 for the clinical details of the patients.

Tissues were obtained within 10 min of delivery. A placental lobule was removed from the central region of the placenta. The basal plate and chorionic surface were removed and villous tissue was obtained from the middle cross-section. Placental tissue was blunt dissected to remove visible connective tissue and calcium deposits. Amnion and choriodecidua were systematically obtained $2 \mathrm{~cm}$ away from the peri-placental edge. After several washes in chilled sterile PBS, tissues were snap frozen and stored at $-80{ }^{\circ} \mathrm{C}$ until ready for
mRNA and protein extraction. Before dissection, preterm placenta and fetal membranes were swabbed for microbiological culture investigations. The preterm placentas were then assessed for histopathological evidence of infection. Of the preterm placentae collected $(n=14)$, eight had confirmed CAM and the remaining six were classified with normal pathology (no evidence of infection or pathological microflora). Placental inflammatory response stages were classified according to Redline $(n=4$ Stage 1 CAM and $n=4$ Stage 2 CAM; Redline et al. 2003, Redline 2006).

\section{RNA extraction and $q R T-P C R$}

Total RNA was extracted from $200 \mathrm{mg}$ frozen tissue using TRI reagent as per manufacturers' instructions and as described previously (Holdsworth-Carson et al. 2009). qRT-PCR was performed by the two-step method. RNA ( $1 \mu \mathrm{g}$ DNase I-treated nucleic acid) was converted to cDNA using iScript cDNA synthesis kit. qRT-PCR reactions (final volume of $25 \mu \mathrm{l}$ ) consisted of Qiagen QuantiTect primer $(1 \mu \mathrm{l}$ for placenta and choriodecidua and $2.5 \mu \mathrm{l}$ for amnion), cDNA (diluted 1:5; $5 \mu \mathrm{l}$ for placenta and choriodecidua and $10 \mu \mathrm{l}$ for amnion) and $12.5 \mu \mathrm{l}$ SensiMixPlus SYBR and fluorescein. An internal $\beta$-actin control was included in each reaction plate. $18 \mathrm{~s}$ ribosomal RNA primers were used for normalization of the data. The cycling conditions for qRT-PCR were as described previously (Holdsworth-Carson et al. 2009). The gRT-PCR was performed using a MiniOpticon 2-colour real-time PCR system (Bio-Rad Laboratories). Opticon Monitor software (Version 3.1.32; MJ Geneworks Inc., and Bio-Rad Laboratories) was used for $C_{\mathrm{T}}$ measurements and melt-curve analysis. Relative mean fold change expression ratios were calculated using the $2^{-\Delta \Delta C_{\mathrm{t}}}$ method using the term group or non-infected preterm group as the calibrators respectively (Livak \& Schmittgen 2001). For CAM amnion analysis, one patient was excluded because the values were determined to be outliers $(>20$ fold excess of the mean), therefore the $n$ value for the Stage 2 CAM group was 3 .

\section{Protein extraction and western blotting}

Nuclear proteins for term versus preterm western blotting analysis were extracted as described previously (Lappas et al. 2002a). Nuclear protein concentrations were determined using the Coomassie Plus Protein Assay. Whole cell protein extraction for preterm infection studies were prepared as described previously (Lappas et al. 2007, Reti et al. 2007). Whole cell protein concentrations were determined using the BCA Protein Assay. Both nuclear and whole-cell protein lysates were prepared in the presence of protease inhibitors $(10 \mu \mathrm{g} / \mathrm{ml}$ aprotinin, $5 \mu \mathrm{g} / \mathrm{ml}$ leupeptin, $1 \mathrm{mM} \mathrm{AEBSF}, 1 \mathrm{mM} \mathrm{Na}_{3} \mathrm{VO}_{4}$ and $1 \mathrm{mM} \mathrm{NaF})$.

Fifty micrograms of protein were resolved in 10\% SDS-PAGE gels at $200 \mathrm{~V}$ for $1 \mathrm{~h}$ and transferred onto PVDF membrane (Millipore Corporation, Billerica, MA, USA) at $105 \mathrm{mAmps}$ for $1 \mathrm{~h}$. The membrane was blocked with $5 \%(\mathrm{w} / \mathrm{v})$ skim milk in TBST for $1 \mathrm{~h}$ at room temperature. Primary antibody incubations occurred for between $2 \mathrm{~h}$ at room temperature to $48 \mathrm{~h}$ at $4{ }^{\circ} \mathrm{C}$, depending on tissue type and antigen. Dilution of 
primary antibody was made in 5\% (w/v) skim milk in TBST. All primary antibody dilutions were 1:250. HRP-conjugated secondary antibody diluted between 1:2500 and 1:5000 was incubated for $30 \mathrm{~min}$ at room temperature. Western blot luminal was used to detect the chemiluminescent signal. Nuclear western blots were normalized using reversible total protein stain, ponceau-S. Whole cell immunoblots were normalized using $\beta$-actin. Densitometry values were measured using quantity one software (Version 4.6.5; BioRad Laboratories). Expression of proteins was calculated as a ratio, with the term group or non-infection group serving as the reference value.

\section{PPAR transcription factor DNA binding activity assay}

Nuclear protein was prepared as described previously (Lappas et al. 2002a) and protein content was determined by Coomassie Plus Protein Assay (Pierce). Transcription factor DNA binding activity was measured using the commercially available PPARA, -D, -G complete transcription factor assay kit following the manufacturers' instructions (Cayman Chemical). Briefly, a dsDNA sequence containing the PPRE is linked onto the bottom of wells (96-well plate). PPARs within the nuclear fraction bind specifically to this sequence and isoforms are detected using primary antibodies directed against the individual PPARs. Clarified cell lysates were supplied for each PPAR isoform and acted as effective positive controls for PPAR DNA binding. Specificity of binding was also demonstrated using wells with no nuclear protein added. In these wells, no binding was detected (data not shown). Binding activity was measured at $450 \mathrm{~nm}$ (minus the blank).

\section{Statistical analysis}

Statistical analyses were performed using a commercially available statistical software package, Statgraphics Plus (Version 3.1; Statistical Graphics Corp., Rockville, MD, USA). Patient clinical information, qRT-PCR, western blot densitometry and PPAR DNA binding activity were analyzed by two-sample comparison and t-test to compare the means. Linear regression analyses were used to evaluate the relationship between fetal membrane rupture duration and expression studies (95\% confidence). Data are expressed as mean \pm s.E.M. Statistical difference was indicated by a $P$ value of $<0.05$.

\section{Declaration of interest}

The authors declare that there is no conflict of interest that could be perceived as prejudicing the impartiality of the research reported.

\section{Funding}

Dr Martha Lappas is in receipt of a National Health and Medical Research Council (NHMRC) RD Wright Fellowship (grant no. 454777). Professor Greg Rice is a NHMRC Principal Research Fellow. The work described in this manuscript was funded by a Melbourne Research Grant Scheme, NHMRC
Project grant (grant no. 367615), Medical Research Foundation for Women and Babies and ANZ Charitable Trust (Medical Research and Technology Grant).

\section{Acknowledgements}

The authors gratefully acknowledge the assistance of Michelle Colomiere (from the Department of Obstetrics and Gynecology, University of Melbourne, Mercy Hospital for Women) for her assistance with qRT-PCR calculations, the Clinical Research Midwives Valerie Bryant, Margaret Cotter, Gabrielle De Bruyn and Anne Beeston, and the Obstetrics and Midwifery staff of the Mercy Hospital for Women for their co-operation.

\section{References}

Ackerman W, Zhang X, Rovin B \& Kniss D 2005 Modulation of cytokineinduced cyclooxygenase 2 expression by PPAR $\gamma$ ligands through NFkB signal disruption in human WISH and amnion cells. Biology of Reproduction 73 527-535.

Barak Y, Nelson M, Ogn E, Jones Y, Ruiz-Lozano P, Chien K, Koder A \& Evan R 1999 PPAR $\gamma$ is required for placental, cardiac, and adipose tissue development. Molecular Cell 4 585-595.

Bensinger S \& Tontonoz P 2008 Integration of metabolism and inflammation by lipid-activated nuclear receptors. Nature 454 470-477.

Berry E, Eykholt R, Helliwell R, Gilmour R, Mitchell M \& Marvin K 2003 Peroxisome proliferator-activated receptor isoform expression changes in human gestational tissues with labor at term. Molecular Pharmacology 64 1586-1590.

Borel V, Gallot D, Marceau G, Sapin V \& Blanchon L 2008 Placental implications of peroxisome proliferator-activated receptors in gestation and parturition. PPAR Research 2008758562.

Capparuccia L, Marzioni D, Giordano A, Fazioli F, De Nictolis M, Busso N, Todros T \& Castellucci M 2002 PPAR $\gamma$ expression in normal placenta, hydatidiform mole and choriocarcinoma. Molecular Human Reproduction 8 574-579.

Daynes R \& Jones D 2002 Emerging roles of PPARs in inflammation and immunity. Nature Reviews Immunology 2 748-759.

Delerive P, Fruchart J-C \& Staels B 2001 Peroxisome proliferator-activated receptors in inflammation control. Journal of Endocrinology 169 453-459.

Dreyer C, Krey G, Keller H, Givel F, Helftenbein G \& Wahli W 1992 Control of the peroxisomal beta-oxidation pathway by a novel family of nuclear hormone receptors. Cell 68 879-887.

Dunn-Albanese LR, Ackerman WE, Xie Y, lams JD \& Kniss D 2004 A reciprocol expression of peroxisome proliferator-activated receptorgamma and cyclooxygenase- 2 in human term parturition. American Journal of Obstetrics and Gynecology 190 809-816.

Fahey J 2008 Clinical management of intra-amniotic infection and chorioamnionitis: a review of the literature. Journal of Midwifery \& Women's Health 53 227-235.

Feingold K, Wang Y, Moser A, Shigenaga J \& Grunfeld C 2008 LPS decreases fatty acid oxidation and nuclear hormone receptors in the kidney. Journal of Lipid Research 49 2179-2187.

Fortunato S \& Menon R 2001 Distinct molecular events suggest different pathways for preterm labor and premature rupture of membranes. American Journal of Obstetrics and Gynecology 184 1399-1406.

Fournier T, Tsatsaris V, Handschuh K \& Evain-Brion D 2007 PPARs and the placenta. Placenta 28 65-76.

French J \& McGregor J 1996 The pathobiology of premature rupture of membranes. Seminars in Perinatology 20 344-368.

Froment P, Gizard F, Defever D, Staels B, Dupont J \& Monget P 2006 Peroxisome proliferator-activated receptors in reproductive tissues: from gametogenesis to parturition. Journal of Endocrinology 189 199-209.

Gargano JW, Holzman C, Senagore P, Thorsen P, Skogstrand K, Hougaard DM, Rahbar MH \& Chung H 2008 Mid-pregnancy circulating cytokine levels, histologic chorioamnionitis and spontaneous preterm birth. Journal of Reproductive Immunology 79 100-110. 
Giannoulias D, Haluska G, Gravett M, Sadowsky D, Challis J \& Novy M 2005 Localization of prostaglandin $\mathrm{H}$ synthase, prostaglandin dehydrogenase, corticotropin releasing hormone and glucocorticoid receptor in rhesus monkey fetal membranes with labor and in the presence of infection. Placenta 26 289-297.

Goldenberg R, Andrews W \& Hauth H 2002 Choriodecidual infection and preterm birth. Nutrition Reviews 60 S19-S25.

Goldenberg R, Culhane JF, lams JD \& Romero R 2008 Epidemiology and causes of preterm birth. Lancet 371 75-84.

Hill M, Young M, McCurdy C \& Gimble J 1997 Decreased expression of murine PPAR $\gamma$ in adipose tissue during endotoxemia. Endocrinology 138 3073-3076.

Holdsworth-Carson S, Permezel M, Riley C, Rice G \& Lappas M 2009 Peroxisome proliferator-activated receptors and retinoid $\mathrm{X}$ receptor-alpha in term human gestational tissues: tissue specific and labour-associated changes. Placenta 30 176-186.

Issemann I \& Green S 1990 Activation of a member of the steroid hormone receptor superfamily by peroxisome proliferators. Nature 347 645-650.

Jiang C, Ting A \& Seed B 1998 PPAR- $\gamma$ agonists inhibit production of monocyte inflammatory cytokines. Nature 391 82-86.

Keelan J, Helliwell R, Nijmeijer B, Berry E, Sato T, Marvin K, Mitchell M \& Gilmour R 2001 15-Deoxy-delta12,14-prostaglandin J2-induced apoptosis in amnion-like WISH cells. Prostaglandins \& Other Lipid Mediators 66 265-282.

Kielian T, Syed M, Liu S, Phulwani N, Phillips N, Wagoner G, Drew P \& Esen $\mathbf{N} 2008$ The synthetic peroxisome proliferator-activated receptor- $\gamma$ agonist ciglitazone attenuates neuroinflammation and accelerates encapsulation in bacterial brain abscesses. Journal of Immunology $\mathbf{1 8 0}$ 5004-5016.

Kim YH, Choi SY, Suh JH, Kim TK, Seung KB, Wang YP \& Chang K 2008 The effect of Chlamydia pneumoniae on the expression of peroxisome proliferator-activated receptor-gamma in vascular smooth muscle cells. Yonsei Medical Journal 49 230-236.

Lamont R 2001 Infection in preterm labour. In Infection and Pregnancy, pp 305-317. Eds A MacLean, L Regan \& D Carrington. London: RCOG Press.

Lappas M, Permezel M, Geogiou H \& Rice G 2002a Nuclear factor kappa B regulation of proinflammatory cytokines in human gestational tissues in vitro. Biology of Reproduction 67 668-673.

Lappas M, Permezel M, Georgiou H \& Rice G 2002b Regulation of proinflammatory cytokines in human gestational tissues by peroxisome proliferator-activated receptor- $\gamma$ : effect of 15 -deoxy-D $(12,14)-P G) 2$ and troglitazone. Journal of Clinical Endocrinology and Metabolism 87 $4667-4672$.

Lappas M, Permezel M, Ho P, Moseley J, Wlodek ME \& Rice G 2004 Effects of nuclear factor-kappa B inhibitors and peroxisome proliferatoractivated receptor-gamma ligands on PTHrP release from human fetal membranes. Placenta 25 699-704.

Lappas M, Permezel M \& Rice G 2007 Mitogen-activated protein kinase proteins regulate LPS-stimulated release of pro-inflammatory cytokines and prostaglandins from human gestational tissues. Placenta $\mathbf{2 8}$ 936-945.

Laws P, Abeywardana S, Walker J \& Sullican E 2007 Australia's mothers and babies 2005. In Perinatal Statistics Series No 20. Sydney: AlHW National Perinatal Statistics Unit.

Lim H \& Dey S 2000 PPAR $\delta$ functions as a prostacyclin receptor in blastocyst implantation. Trends in Endocrinology and Metabolism 11 137-142.

Lindstrom T \& Bennett P 2005 15-Deoxy-D12,14-prostaglandin J2 inhibits interleukin-1b-induced nuclear factor- $\mathrm{\kappa} B$ in human amnion and myometrial cells: mechanisms and implications. Journal of Clinical Endocrinology and Metabolism 90 3534-3543.

Livak K \& Schmittgen T 2001 Analysis of relative gene expression data using real-time quantitative PCR and the 2-DDCT method. Methods 25 402-408.

Mangelsdorf D \& Evans RM 1995 The RXR heterodimers and orphan receptors. Cell 83 841-850.

McParland P \& Bell S 2004 The fetal membranes and mechanisms underlying their labour-associated and pre-labour rupture during pregnancy. Fetal and Maternal Medicine Review 15 73-108.
Van Meir C, Sangha R, Walton J, Matthews S, Keirse M \& Challis J 1996 Immunoreactive 15-hydroxyprostaglandin dehydrogenase (PGDH) is reduced in fetal membranes from patients at preterm delivery in the presence of infection. Placenta 17 291-297.

Van Meir C, Matthews S, Keirse M, Ramirez M, Bocking A \& Challis J 1997 15-Hydroxyprostaglandin dehydrogenase: implications in preterm labor with and without ascending infection. Journal of Clinical Endocrinology and Metabolism 82 969-976.

Meirhaeghe A, Boreham CA, Murray LJ, Richard F, Davey Smith G, Young IS \& Amouyel P 2007 A possible role for the PPARG Pro12Ala polymorphism in preterm birth. Diabetes 56 494-498.

Menon R \& Fortunato SJ 2004 The role of matrix degrading enzymes and apoptosis in rupture of membranes. Journal of the Society for Gynecologic Investigation 11 427-437.

Perez A, van Heeckeren A, Nichols D, Gupta S, Eastman J \& Davis P 2008 Peroxisome proliferator-activated receptor- $\gamma$ in cystic fibrosis lung epithelium. American Journal of Physiology. Lung Cellular and Molecular Physiology 295 L303-L313.

Premyslova M, Li W, Alfaidy N, Bocking A, Campbell K, Gibb W \& Challis J 2003 Differential expression and regulation of microsomal prostaglandin E2 synthase in human fetal membranes and placenta with infection and in cultured trophoblast cells. Journal of Clinical Endocrinology and Metabolism 88 6040-6047.

Redline R 2006 Inflammatory responses in the placenta and umbilical cord. Seminars in Fetal \& Neonatal Medicine 11 296-301.

Redline R, Faye-Petersen O, Heller D, Qureshi F, Savell V \& Vogler C 2003 Amniotic infection syndrome: nosology and reproducibility of placental reaction patterns. Pediatric and Developmental Pathology 6 435-448.

Reti NG, Lappas M, Riley C, Wlodek M, Permezel M, Walker S \& Rice G 2007 Why do membranes rupture at term? Evidence of increased cellular apoptosis in the supracervical fetal membranes American Journal of Obstetrics and Gynecology 196 484e.1-484e.10.

Ricote M, Li A, Willson T, Kelly C \& Glass C 1998 The peroxisome proliferator-activated receptor-gamma is a negative regulator of machrophage activation. Nature 391 79-82.

Rodie V, Young A, Jordan F, Sattar N, Greer I \& Freeman D 2005 Human placental peroxisome proliferator-activated receptor $\delta$ and $\gamma$ expression in healthy pregnancy and in preeclampsia and intrauterine growth restriction. Journal of the Society for Gynecologic Investigation 12 320-329.

Romero R, Espinoza J, Goncalves L, Kusanovic J, Friel L \& Nein J 2006 Inflammation in preterm and term labour and delivery. Seminars in Fetal \& Neonatal Medicine 11 317-326.

Saigal S \& Doyle L 2008 An overview of mortality and sequelae of preterm birth from infancy to adulthood. Lancet 371 261-269.

Schaiff WT, Barak Y \& Sadovsky Y 2006 The pleiotropic function of PPARg in the placenta. Molecular and Cellular Endocrinology 249 10-15.

Tarrade A, Schoonjans K, Pavan L, Auwerx J, Rochette-Egly C, Evain-Brion D \& Fournier T $2001 \mathrm{PPAR} \gamma / \mathrm{RXR} \alpha$ heterodimers control human trophoblast invasion. Journal of Clinical Endocrinology and Metabolism 86 5017-5024.

Waite L, Person E, Zhou Y, Lim K, Scanlan T \& Taylor R 2000 Placental peroxisome proliferator-activated receptor-g is up-regulated by pregnancy serum. Journal of Clinical Endocrinology and Metabolism $\mathbf{8 5}$ 3808-3814.

Wang Q, Fujii H \& Knipp GT 2002 Expression of PPAR and RXR isoforms in the developing rat and human term placentas. Placenta 23 661-671.

Wieser F, Waite L, Depoix C \& Taylor R 2008 PPAR action in human placental development and pregnancy and its complications. PPAR Research 2008 1-14.

Yang W-L \& Frucht H 2001 Activation of the PPAR pathway induces apoptosis and COX-2 inhibition in HT-29 human colon cancer cells. Carcinogenesis 22 1379-1383.

Received 27 November 2008

First decision 19 December 2008

Revised manuscript received 4 March 2009

Accepted 11 March 2009 